DOI https://doi.org/10.18551/rjoas.2017-09.10

\title{
TECHNOLOGICAL INNOVATION AND BUSINESS DIVERSIFICATION: SUSTAINABILITY LIVELIHOODS IMPROVEMENT SCENARIO OF RICE FARMER HOUSEHOLD IN SUB-OPTIMAL LAND
}

\author{
Adriani Dessy ${ }^{1,2 *}$, Wildayana Elisa ${ }^{1}$, Yulius $^{1}$, Alamsyah Idham ${ }^{1}$, Hakim Maryati Mustofa ${ }^{1}$ \\ ${ }^{1}$ University of Sriwijaya, Palembang, Indonesia \\ ${ }^{2}$ Center of Excellence Peatland Conservation and Productivity Improvement (CoE PLACE), \\ University of Sriwijaya, Palembang, Indonesia \\ *E-mail: dessyadriani@fp.unsri.ac.id
}

\begin{abstract}
The increased role of the sub-optimal land to support food security continue to be encouraged in Indonesia, given the more limited expansion for potential land. But until recently, development of sub-optimal land becomes not an easy thing. Ecological and technical barriers became the main issue. A series of these issues resulted in a high number of underemproleymeny and poverty in agriculture region. Technological inovation of agriculture and the business diversification can be seen be the solution to those issues. This research aims to analyze the impact of the technological innovation and business diversification on underemployment, working time, household income and also sustainable livelihoods of farmers on the sub-optimal land. The research was carried out in Pemulutan District, Ogan Ilir Regency, South Sumatra Province, Indonesia. The objects of research are farmers which adopter and non adopter technological innovation, and also work outside of paddy farming (business diversification). The research method is the survey. Method of sampling is stratified random sampling. Data obtained in the field analyses using descriptive statistics and inferesia. The results showed there are positive impact of technological innovation on the allocation of working time farmer households, the numbers underemployment, household income and livelihood sustainability. Determinant factors for farmers in applying technology and business diversification are paddy farming income, offfarm income, and age. The use of technology and business diversification proves to be one of the positive scenarios for sustainable livelihood of farmers in sub-optimal land.
\end{abstract}

\section{KEY WORDS}

Underemployment, diversification, technology, livelihoods, sustainability, sub-optimal land.

The agricultural sector in Indonesia is largely built by farmers. Thus, the welfare of farmers should be a concern. The increased role of the sub-optimal land to support food security continue to be encouraged in Indonesia, given the more limited expansion for potential land in food production. But until recently, development of sub-optimal land becomes not an easy thing. The efforts of agricultural development in sub-optimal land extremely complex from upstream (production) to downstream (post harvest). The complexity of the issue also involved multi-stakeholders with their each interest that are interlinked with each other (interdependent) in one system. The above problems togethered with the low productivity of the sub-optimal land, the limitations of labour, low levels of knowledge of farmers, agricultural custom subsystems, limitations of capital, infrastructure sub-optimal irrigation limited, as well as high levels of pests-diseases in plants, also caused a sub-optmal land to be difficult managed (Riyani, 2013; Panggabean, E.W., and B.Y. Angunniko, 2014; Alwi, 2014).

With the variety of problems facing by farmers in the household, so that the farmers majority in sub-optimal land trapped in poverty. Poverty reduction strategies based on the argument that with high economic growth, poverty will be reduced through the mechanism of a trickle down effect have yet to deliver maximum results in the region. One thing that needs to be understood that factors social, economic and culture is often seen as an important 
element that determines the resolution of various issues above.

Benjamin, L., and N. Gofar (2013), the development of the sub-optimal land need to be prioritized in the technological development of that are technically relevant to the respective characteristics of the suboptimal land, economically affordable by local farmers, as well as expected also in tune with the preferences and socio-cultural community. To realize the sustainability of suboptimal land management, then all the technical and technological efforts undertaken should also consider the possibility of impact ecologisnya, sosioculturale compliance with the local community, in addition to the obviously economically profitable for farmers as the main producer in food production.

Technological innovation is a term that has been used widely in many fields, both agricultural and non agricultural. Adams (1988); Simamora (2003); and Kotler (2003) states, technological innovation is an idea, practice, or new products that are considered by the individual or group that is relevant. Musyafak and Ibrahi (2005) states one of the factors that affect the acceleration of the adoption of technological innovations is the nature of the innovation itself. Innovations introduced must have a lot of conformity (adaptive power) against the conditions of the biophysical, social, economic, and culture that exists on the farmers. So that, the innovation offered to swamps land farmers should be appropriate innovations.

South Sumatra (Sumatra) is a one of main area for rice production in Indonesia, the sixth in Indonesia or the third in outsite of Javanese after South Sulawesi and North Sumatra. The trend of harvesting, production, and productivity of rice in South Sumatra from 1991 until the year 2014 shows increasing. This is supported by the availability of potential land resources are quite varied, ranging from wetland irrigation, rainwater, tidal marshes, lebak, and dry land. Rice paddy field South Sumatra in 2012 is about 443,199 hectares and with the application of technological innovation to the planting area of rice then South Sumatra could reach 800,615 hectares by the year 2014 . The swamps land which has been used for rice cultivation in South Sumatra, about 304,563 hectares or approximately 38 per cent of padi land South Sumatra.

The swamps land is one of the sub-optimal land potential to be developed. Ogan Ilir Regency is one of regencies in South Sumatra which is the center of swamp land in Soutn Sumatera. Ogan Ilir Regency is a region with the second largest of Swamp land in South Sumatra. This area has the potential land covering an area of swamp land 63,503 hectares, cultivated area for once per year was hectare 49,092 hectares, while not cultivated area of 7,617 hectares of land, and only an area of 137 hectares are planted with two times per year. If we refer to the data, there is still the potential for land use in the Ogan llir swamp land, where just 137 acres was done twice planting. For such purposes, of course needed any agriculture innovations.

Freeman (2005) stated the implementation of an innovation is one of the main keys in the utilization of limited resources condition in each region; as well as in the sub-optimal land. The ecological problems faced by farmers is the availability of water at any given time, so that in this region most farmers could only plant 1 time a year (Cropping Index 100). In contrast to the area of iirigated land, for example, can plant rice up to three times a year (Cropping Index 300). For increased, cropping index in the sub-optimal land, then the technology is a must. Beginning in 2015, the government has launched various packages of technology that have an impact on the increase of the cropping index be 200 in sub-optimal land. Technology package are water treatment and agricultural integrated plant technology. With this package of technology, then the beginning of land can only be cultivated one time increased to twice. Not only that, the application of innovations in the cropping pattern that can actually increase utilization of swapt land

In addition, besides to the cropping index is still low, the issue of sub-optimal land are also related to the high underemployment, due to the limited selection of work that can be done. Some of the last results shows, the increasing of underemployment in the agricultural sector. Adriani (2015), there are 627.67 hours for labor potential times available in household. With the allocation of working time on the farming of rice of 55.85 hour, and 571.82 hours for underemployment. This is supposed to be a covert underemployment 
allocated on other productive sectors in on-farm (soybeans, corn and beans, etc) and offfarm (labour, stalls, merchants, and so on). With underemployment condition, farmers rationally and economically used their time for diversify the structure of the work (business diversification). Work time allocation covers how the behavior of households in adjusting on the constraints of existing employment opportunities and with the resources that belong to fullfill his needs. According to Becker (1965); Gronau (1976); Nakajima (1986); and Fabrerro and Schwartz (2000), the allocation of working time explained that the individual economically allocate his time in the labour market, to get a reward and satisfaction of the allocation of time to work outside of wages. Thus, farmers do diversify of bussiness to improve his livelihoods. Business diversification is an important decision and very rational to be taken by the farmer's household, although in fact not all farmer households unable or unwilling to execute it. With limited resources, owned then the vulnerable households or who have yet to choose alternative income household Precision farmers in taking decisions in conditions of risk will largely determine the sustainability of penghidupannya.

Based on the results of the above description, it is noted that the research on technological innovation in technics and Economics and relation to other businesses outside of the diversification of rice have already been done, but its impact on the increase in work time, the reduction of underemployment, income, and sustainability of livelihoods have not been much researched. Therefore, this study aimed to analyze the specific impact of the application of technological innovations and businesses diversification on the allocation of working time, the reduction of underemployment, income and sustainability of livelihoods, as well as the factors that influence the allocation of working time. The results of this study are expected to provide input for the improvement of the income of farmers so that the farmers ' welfare can be achieved.

The objectives of research are:

1. To analyze the impact of technological innovation and business diversification on the allocation of household working time, underemployment, income and livelihood sustainability.

2. Analyze the factors that influence the allocation of working time household farmers who use technological innovation and do business diversification on the land sub-optimal.

Hypothesis:

1. Expected that there are positif impact of technological innovation and business diversification on the allocation of working time, underemployment, income and livelihood sustainability of adopter farmer household in sub-optimal land.

2. Expected that age of farmers, on-farm income (rice and non rice farming income) and off-farm income influenced positive significantly, while the members number of the family and the educational factors influenced negative significantly to the allocation of working time adopter farmer household in sub-optimal land.

\section{METHODS OF RESEARCH}

This research was carried out in Pemulutan District Ogan Ilir Regency. This research was carried out in February 2017. The research method was survey methods, in which the sample are (1) farmers who does not adopt the technology (IP-100) and (2) farmers who adopt technological innovation (IP 200) and also done business diversification. Sampling methods were disproportionate stratified random sampling. Data collection is done through interviews using questionnaire method. In total, 120 farmers were selected at two category from these areas. Data obtained in the field processed in tabulations, calculated mathematically and descriptive quantitatively. To calculate the allocation of working time households, calculated the average amount of time each activity for one year and then explained in the descriptive. To answer the first purpose and hypothesis about the existence of the difference of the technological innovation of farming on the allocation of household work time, underemployment, income, and livelihoods sustainability of farmer households conducted in tabulative, followed by t-testing. To answer the second hypothesis about the purposes and the factors those influence the allocation of working time household farmer innovation and also done business diversification done by multiple linear regression method. 


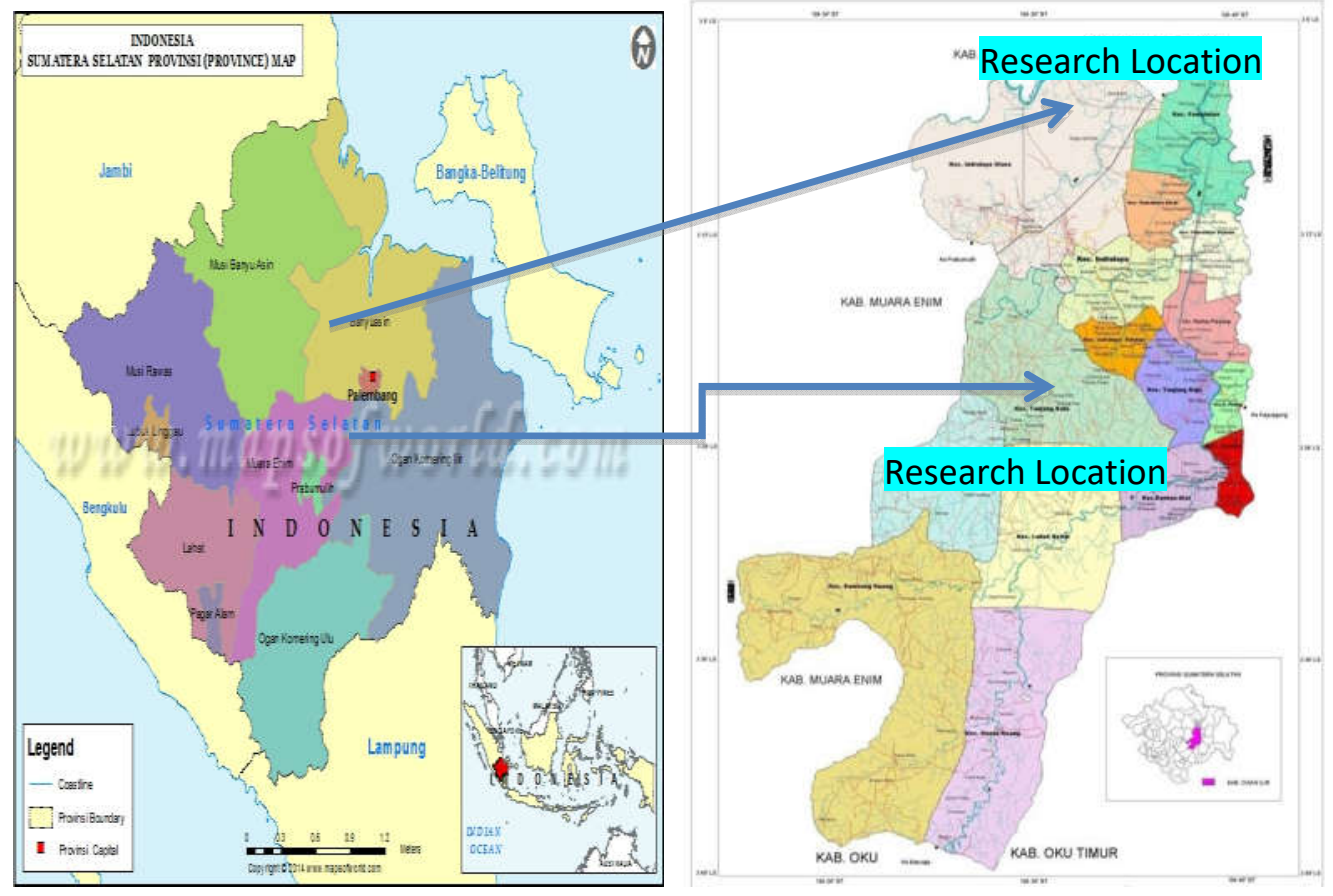

Figure 1 - Research Location

Definitions:

1. Non-adopter is farmers household that didn't apply technological innovation (using cropping index 100).

2. Adopter is farmers households that apply technological innovation (using cropping index 200).

3. The potensial working time allocation is the total working time of farmer households in normal condition, that is 300 for man and 226 for woman.

4. The actual working time allocation is the actual working time that is used by farmer household comes from within the family in activities of on-farm (both rice farming and non-rice farming) and off-farm.

5. Underemployment is the difference between the potensial working time and the actual working time allocation

6. Bussiness diversification is the bussiness of farmers household comes from on-farm and off-income activities.

7. On-farm income activities from (1) rice farming income and (2) non rice farming income such as corn, longleans, soybeans, and livestocks.

8. Off-farm income activities outsite of farming that is laborers, traders, drivers, and so on.

\section{RESULTS AND DISCUSSION}

The Impact of Technological Innovation and Bussiness Diversification to Underemployment and Working Time Allocation of Sub-optimal Land Farmer Household. Detection of underemployment in the sub-optimality land is performed by calculating in advance the potential work force and the allocation of working time in the household for (1) non adopter and (2) adopter farmer who also done business diversification. The allocation of actual working time is the working time that is used by farmers comes from within the family in activities of on-farm (both rice farming and non-rice farming) and off-farm. Rice farming for non adopter farmer households are conducted once in a year, carried out in the month of April until the month of August. Table 1 presents working time for non adopter is 10.39 workingday/households/year, will undergo underemployment amounting to 687.74 workingday/household/year or $98.51 \%$ of a their total potential working time. 
Table 1 - The Potential Working Time, Actual Working Time and Underemployement for Non Adopter Rice Farmer Households in Sub-optimal Land, 2017

\begin{tabular}{cccc}
\hline No. & Description & $\begin{array}{c}\text { Working Time Allocation } \\
\text { (workingday/ household/year) }\end{array}$ & Percentage (\%) \\
\hline 1 & Actual Working Time & 10.39 & 1.49 \\
2 & Underemployment & 687.74 & 98.51 \\
\hline & Potential Working time & 698.13 & 100.00 \\
\hline
\end{tabular}

But if the farmer is adopter of technological innovation (with Cropping index 200), then the case of underemployment decrease to become 672.61 workingday/household/year. Rice farming with technological innovation is able to absorb into the work potential of 3.66 percent available, from previously only 1.49 percent. With the application of technology, there is an increase in working time of 2.17 percent followed by the reduction of underemployment by the same percentage (Table 2).

Table 2 - The potential, working time Farmers and unemployed Veiled on farmers Land in Technology Practitioners Sub Optimal, 2017

\begin{tabular}{cccc}
\hline No. & Description & $\begin{array}{c}\text { Working Time Allocation } \\
\text { (workingday / household/year) }\end{array}$ & Percentage (\%) \\
\hline 1 & Actual Working Time & 25.53 & 3.66 \\
2 & Underemployment & 672.61 & 96.34 \\
\hline & Potential Working time & 698.13 & 100.00 \\
\hline
\end{tabular}

Thus, without technological innovation, the incidence of underemployment will be higher. Furthermore, in order to resolve underemployment, households of farmers also diversified structure of the bussiness. A selection of the work being done is on-farm (rice and non-rice) and off-farm (Labour, drivers, trader, and so on).

Table 3 - Work time allocation of household for Adopter with Business Diversification in Sub-optimal Land, 2017

\begin{tabular}{cccc}
\hline No. & Bussiness Diversification & Working Time & Percentage (\%) \\
\hline 1 & On Farm-Rice & (Working Day /Household/Year) & 20.56 \\
2 & On Farm-Non Rice (Corn, longbeans, soybean, livestock) & 34.53 & 27.63 \\
3 & Off-farm (laborer,traders,drivers) & 64.33 & 51.81 \\
\hline & Total & 124.16 & 100.00 \\
\hline
\end{tabular}

Allocation of working time in off farm activities is 64.33 workingday/household/year, then on farm-rice 25.53 workingday/household/year dan on farm-non rice 34.30 workingday/household/year (Table 3 and Figure 2). Thus, bussiness diversification can improve the allocation of working time farmer households from 25.53 workingday/household/year to 124.16 workingday/household/year (Table 4).

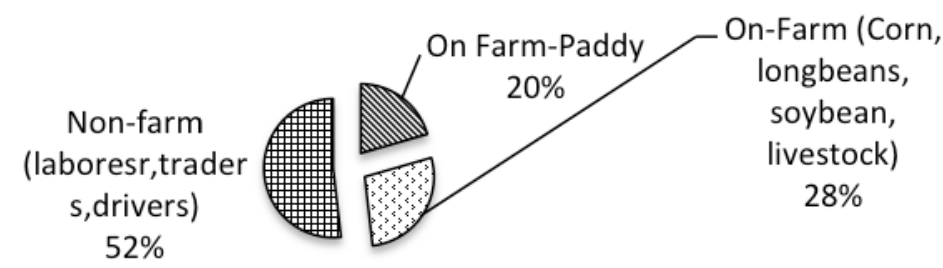

Figure 2 - Work time allocation for Adopter with Bussiness Diversification in Sub-optimal Land, 2017

Analysis results in Table 4 indicates that business diversification on activities of onfarm and off farming impact on increasing work time allocation amounting to 124.16 workingday/households/year or increased by 386.39 percent. Diversification also encouraged a decrease in underemployment 98.64 workingday/households/year (-14.66\%). 
Table 4 - Change Working time farmers and Covert Unemployment in Households with Diversified Innovation Practitioners Work in Sub-Optimal, 2017

\begin{tabular}{cccccccc}
\hline & & \multicolumn{2}{c}{$\begin{array}{c}\text { Adopter Without } \\
\text { Diversification }\end{array}$} & \multicolumn{2}{c}{ Adopter With Diversification } & \multicolumn{2}{c}{ Change } \\
\cline { 3 - 8 } No. Description & $\begin{array}{c}\text { Working Time } \\
\text { (Working Day } \\
\text { /Household/Year) }\end{array}$ & $\begin{array}{c}\text { Percentage } \\
(\%)\end{array}$ & $\begin{array}{c}\text { Working Time } \\
\text { (Working Day } \\
\text { /Household/Year) }\end{array}$ & $\begin{array}{c}\text { Percentage } \\
(\%)\end{array}$ & $\begin{array}{c}\text { Working Time } \\
\text { (Working Day } \\
\text { /Household/Year) }\end{array}$ & $\begin{array}{c}\text { Percentage } \\
(\%)\end{array}$ \\
\hline 1 & $\begin{array}{c}\text { Actual Working } \\
\text { Time }\end{array}$ & 25.53 & 3.66 & 124.16 & 17.79 & 98.64 & 386.39 \\
2 & Underemployment & 672.61 & 96.34 & 573.97 & 82.21 & -98.64 & -14.66 \\
\hline $\begin{array}{c}\text { Potential Working } \\
\text { time }\end{array}$ & 698.13 & 100.00 & 698.13 & 100.00 & & \\
\hline
\end{tabular}

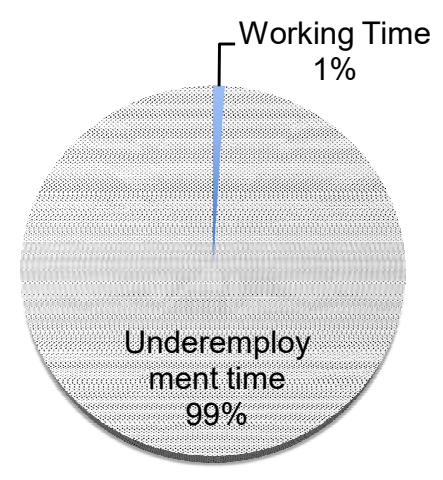

Without Technology

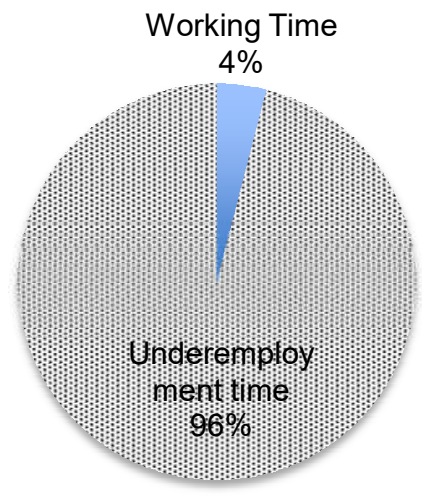

With Technology, Without Bussiness Diversification

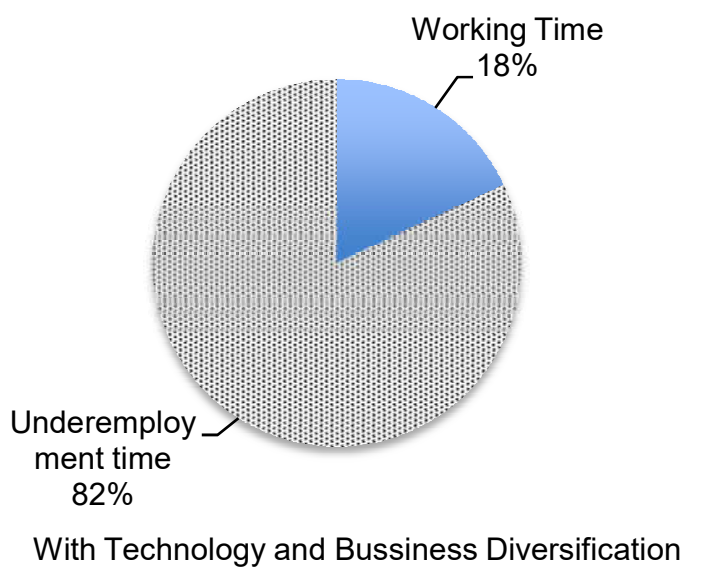

Figure 3 - Comparison of the allocation of working time and unemployment is veiled for farmers instead of technology practitioners, practitioners of technology with and without the Diversification Effort 
Furthermore Figure 3 presents a comparison of the allocation of working time and underemployment for non adopter farmers and adopter farmers with and without the bussiness diversification. It can be concluded that technological innovation and bussiness diversification can improve the allocation of time and reduce underemployment.

The t-test shows the same result. The t-value is 5.669 with df 58 and $\alpha=0.05$. The value of tabel in df 58 with $\alpha=0.05$ is 1.671 so the obtained conclusions based on t-test value $>$ t-test tabel $(5.669>1.671)$ reject $\mathrm{H}_{0}$, meaning that the allocation of time to work for adopter with business diversification is much larger than non adopter farmers. In other words, technological innovation can significantly reduce underemployment in a significant way.

But the results of this research strengthen new facts, that the choice of a job that can be done by farmers are very limited in rural area. Thus, even though farmers have been doing a lot of things to optimize the allocation of time, yet the percentage of underemployment in the region remains high. Therefore, the policy of the government is required relate to the creation of new employment opportunities in rural areas. Employment opportunities are not only related to the addition of a number of job opportunities, but also increasing productivity coupled with farmers. Industrial agriculture also remains necessary to encourage the development of the creation of employment opportunities.

The results of this study are contrary to many previous research results that reveal the negative impact of the use of technology in the agricultural sector as has been revealed by Acemoglu, D. (2002) and Bartelsman et al., (2010), the use of technology in the field of agriculture gave rise to many problems. The use of technology does not necessarily increase productivity significantly. Another issue that arises is related to a decrease in the use of labour, the loss of the job for as the poor population who do not have land, reinforcing inequality, monopoly to the forefront for the owner of the technology, and the potential conflicts in society.

The results of this study at least suggest that the use of technology in a way that is appropriate and wise thus provide a positive impact for the community. The use of technology in the agricultural sector is a must for the progress of the agricultural sector. Thus, it should think about is the increased of technological innovation is accompanied by an increase in employment opportunities. One of them through an increase in the productivity of farmers, not only in on farm but also in off the farm.

The Impact of Technological Innovation and Businesses Diversification on Income and Livelihood Sustainability of Farmer Households in Suboptimal Land. The increase of income is the farmers expected by applicated of technological innovations and bussiness diversification. The results of this research show that technological innovation in the suboptimal land can increase the income of farmers. Technological innovation not only has an impact on the allocation of working time farmers, but also on the rice farming income as presented in Figure 5.

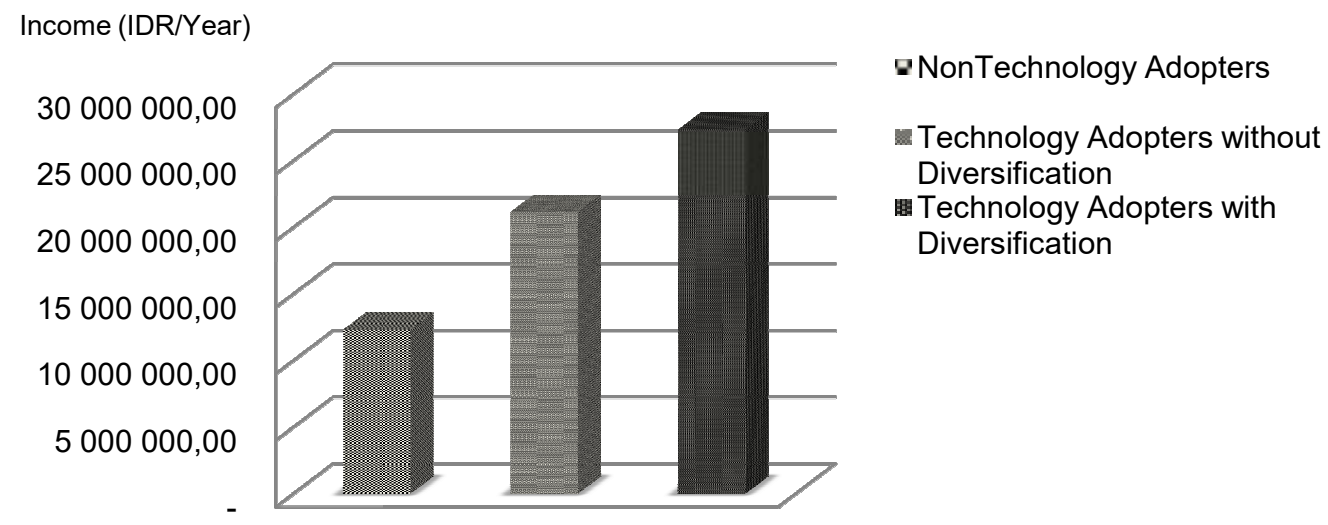

Figure 4 - Comparison of Income between Farmers Household for Non Technology Adopters, Technology Adopters with and without Diversification, 
$\mathrm{t}$-Test results indicates that the t-value is 8.323 with $58 \mathrm{df} 8.323$ and $\alpha=0.05$. The value of t-tabel in df 58 with $\alpha=0.05$ is 1.671 so the obtained conclusions based on t-test thitung $>$ value is ttabel $(8.323>1.671)$ reject $\mathrm{H}_{0}$, this indicates the income of adopter farmers is larger than non adopters farmers who do not use the innovation of farming. This shows that the first hypothesis is suspected the existence of a positive impact of technolocigal innovation and business diversification on the allocation of household work time and income.

If then, analysis of farmers ' income was more focused on technology adopters and also diversify, then Table 5 presents the total household income earned amounting to $\mathrm{Rp}$ $27,335,452.00 / y e a r$. When compared to the farmers instead of technology adopters, then an increase in income of $121.86 \%$.

Table 5 - Total household income for Technology Adopters with Business Diversification, 2017

\begin{tabular}{lll}
\hline \multicolumn{1}{c}{ Income Diversification } & Income (IDR/Year) & Percentage (\%) \\
\hline On Farm-Paddy & $21,162,119.00$ & 77.42 \\
On-Farm (Corn, longbeans, soybean, livestock) & $1,863,333.00$ & 6.82 \\
Non-farm (laboresr,traders,drivers) & $4,310,000.00$ & 15.77 \\
\hline Total & $27,335,452.00$ & 100.00 \\
\hline
\end{tabular}

Figure 6 presents that income from rice farming contributed most $(77 \%)$ to the total household income of farmers, followed by income from off the farm of $16 \%$. In choosing good alternative livelihoods to its addition in order to enlarge the owned assets or because of having to cover the needs of the family, then the most noteworthy consideration is whether household farmers still able to undertake such activities. It is given the circumstances of physical ability and limited capital as well as requiring mastery of innovation and adequate information.

Based on the structure of jobs, jobs as merchants are found in all areas of research. Likewise, the livestock business. While trade and building materials more concentrated in certain regions. An important aspect in the development of diversified business was the availability of leisure time of the family member. From Table 4, clearly that free time for off farm activities is still available potentially for $573.97 \mathrm{HOK} /$ household/year $(82.21 \%)$. If the household uses only time it works is less than 30 percent a year, then it seems that underemployment has occurred in the suboptimal area.

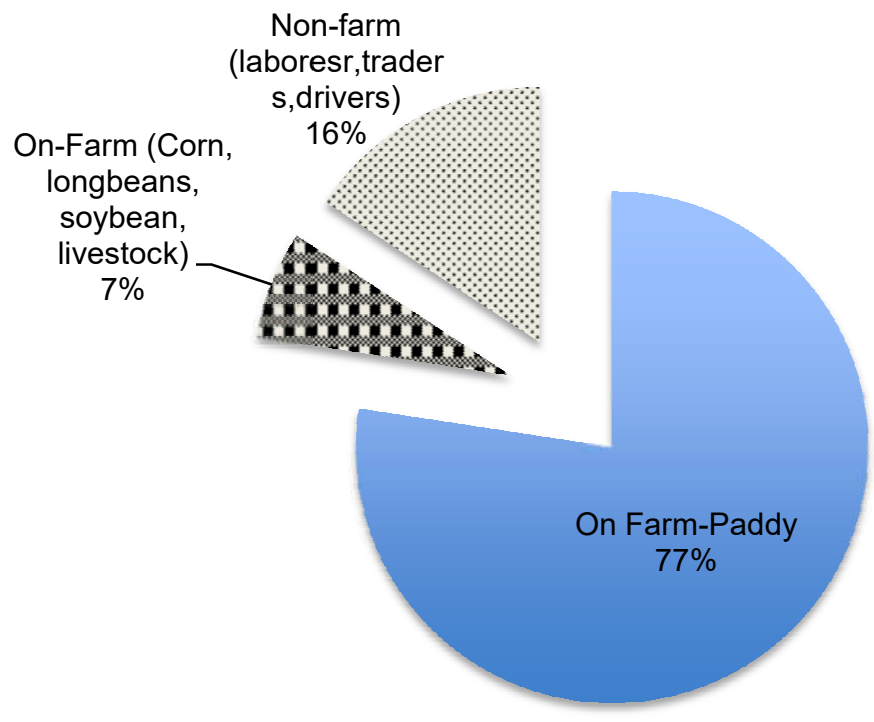

Figure 6 - Share of Total household income for Technology Adopters with Business Diversification

Doing some alternative livelihood options in terms of household livelihood sustainability while protecting the assets of households is something a wise decision. Household decisions 
in the business diversification will be more precise if alternative livelihoods or businesses contribute increasingly to the total household income. According to Ellis (200), farmer households have 5 kinds of assets that greatly affect the economic activities of households i.e. natural capital (land and potential on it), the physical form of road access and proximity, humans as a source of manpower, financial investment and capital as a force of social activities collectively accelerate mutual. In that condition, the economic activities in the household does not only consist of production, consumption and labor supply, but there are also investment activity that play a role in enhancing the capabilities of sustainable household livelihoods.

The strategy of diversification of household business relies on the ability of households in responding to the diverse livelihood as a business opportunity is accompanied and it should be in line with the program implemented by the Government. With the condition of household economic constraints, regardless of choice of alternative businesses outside the farming still need the support from parties, because in fact all such endeavor requires capital does little to its sustainability.

This research result shows that technological innovation and business diversification give opportunities for farmers' household in increasing livelihoods sustainability.

The Determinant Factor in Allocation of Working Time of Adopter Farmer with Business Diversification. Factors that influence the allocation of working time in applying technological innovation with business diversification consists of economic factors and social factors. Prediction value of the parameters in the equations used multiple linear regression analysis by using applications SPSS 17.0. The results of estimation present factors namely on farm income (rice and non rice), off farm income farm income, education, age and number of family members influenced the allocation of working time of farmer household in technological innovation with business diversification as can be seen on table 6 .

The value of the coefficient determination $\left(R^{2}\right)$ of 0.439 which means that on farm income (rice and non rice), off farm income farm income, education, age and number of family members and the rest of 56.10 percent is explained by other variables that are not included in the model.

The value of F-statistics (Fhitung) obtained from the regression result is 3.000 where $\mathrm{F}$ value greater than F-tabel with $\alpha=0.05$ i.e. 2.53 , so hypothesis nol $\left(\mathrm{H}_{0}\right)$ is rejected and accepted the alternative hypothesis $\left(\mathrm{H}_{\mathrm{a}}\right)$. This indicates on farm income (rice and non rice), off farm income farm income, education, age and number of family members influenced on the allocation of working time farmer households on $\alpha=0.05$.

Economically, the estimation are good when the five of the six sign of regression coefficients are obtained from the results is in compliance with economic theory. Variables which have the positive sign is on farm income (rice and non rice), off farm income, education, age, while variables with a negative sign is the number of family members.

Table 6 - The results of estimation for the allocation of working time farmers household equation in Sub-optimal Land, 2017

\begin{tabular}{|c|c|c|c|c|c|c|}
\hline \multicolumn{7}{|c|}{ Estimation Result } \\
\hline Independent Variable & $\begin{array}{c}\text { Regression } \\
\text { Coefficient }\end{array}$ & t-hitung & Prob-t & Tolerance & VIF & Note \\
\hline Constanta & $-50,094$ & $-1,748$ & 094 & & & \\
\hline Rice on Farm Income & 7,891E-7 & 2,103 & 047 & ,790 & 1,266 & * \\
\hline Non-Rice on Farm Income & 6,495E-7 & 678 & ,505 & 813 & 1,230 & - \\
\hline Off Farm Income & $1,286 \mathrm{E}-6$ & 1,622 & ,018 & ,700 & 1,429 & * \\
\hline Age & 1,018 & 2,235 & ,035 & ,504 & 1,985 & * \\
\hline Education & 1,928 & 1.052 & ,304 & ,430 & 2,327 & - \\
\hline $\begin{array}{c}\text { Number of Family } \\
\text { Members }\end{array}$ & $-2,440$ &,- 980 & ,337 & ,879 & 1,137 & - \\
\hline
\end{tabular}

$R^{2}=0,439$ F-hitung $=3,000$

In econometrics, the regression equation estimated that they would not be analyzed the problem of autocorrelation. Durbin Watson value obtained is amounting to 1.377 . If tested 
with a test using the Durbin Watson (DW) obtained results $\mathrm{dl}=0.9256$ and $\mathrm{du}=2.0343$, where DW is located between the dl and du, then retrieved the results $0.9256<2.0343<$ meaning 1.377 such values are inconclusive as to whether the positive autocorrelation occurred, or not going negative autocorrelation autocorrelation. But according to Pindyck, $r$. s. and d. I. Rubienfeld (1991) autocorrelation problem only affects efficiency prediction and does not affect to prediction bias. One thing that is most important and became the main orientation of this research are all signs of the estimated parameter in the model correspond to the expectations based on theory as well as economic logic. The regression equation that analyzed, also doesn't indicate the multikolinierity problem. Relation between two variables independent is free because the value of variance inflation factor (VIF) is not more than 10 . The results of the scatter plot in SPSS output does not indicate the existence of a certain pattern so that it can be concluded that no also occurrence of heteroskedastisitas on the regression equations.

A significant level of test-t is used to see the influence of each free variable i.e. on farm income (rice and non rice), off farm income farm income, education, age and number of family members who have an effect on the allocation of working time farmer households. Free variables that affect the allocation of working time economically positive and significant in statistics is on farm income (rice), off farm income farm income, and age, whereas a non influential variables are not real other on farm income (rice), education, and the number of family members.

Rice on-farming income has a positive affect to the allocation of working times farmer household in sub-optimal, whereby any income increase of rice farming at Rp 1.00 , then it would cause an increase in the amount of household work time allocation of $7.891 \times 10-7$ HOK. The higher income gained by farmers adopter farming in sub-optimal land, then the allocation of working time that household used by farmers in are also higher due to the more land area owned, then the number of capital that are used are also high because the time allotted is not much anyway. This will affect the income of rice farming rice and the amount of work time allocation used by farmers in the land. To that end, rice farming income gained by farmers is positive towards the allocation of working time farmer households.

The regression coefficient values for off farmi income has a positive affect toward the allocation of working time households farmer which means any addition of other farming

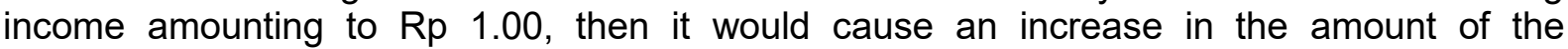
allocation of working time farmer households of $6.495 \times 10-7 \mathrm{HOK}$. It is also evidenced in the field that in other farming activities such as raising fish, chicken, or duck, farmers use of labor in the family i.e. husband and wife so that the income earned by farmers in other farming activity increased.

Variable for the age of farmer also had a positive influence to the allocation of working time farmer households. The fact that the average age of farmers is 45 years old. The more the increasing age of the farmers, then the allocation of working time used will also increase until eventually the farmers have entered old age and do not have a physical and strong power again to do the farming of rice, and finally more use outside of the family labor (labor wages) for rice farming activities.

The results of the analysis with multiple linear regression model shows that the factors that influence positively to the allocation of working time farmer household is rice on farm income, off income, and age. Almost all the income variables examined the real effect to the allocation of working time. This means that the acquisition of income remains a major factor of farmers to work. almost The influencing of all of the income variable indicates that income is an important thing that makes farmers decide to add their hours of work. In other words, economic motives still continues to be the reason for farmers to work. These results are in line with research Adriani (2015) which states that the farmers have rationality in social and economic activities of farming. This study shows that the use of technology and business diversification proves to be one of the positive scenarios for sustainable livelihood of farmers in sub-optimal land. 


\section{CONCLUSION}

Existence of the positive impact of the use of technological innovation of farming and business diversification efforts to increased allocation of working time, to decrease underemployment, income generating and livelihood of rice farmers ' households in sub optimal land. Factors that effect positive and significantly to the allocation of working time farmers household who use technology and also to diversify is rice on-farm income, off-farm income, and age. And so that, the use of technology and business diversification proves to be one of the positive scenarios for sustainable livelihood of farmers in sub-optimal land.

\section{ACKNOWLEDGEMENT}

This paper is part of the Grant Competitive Universitas Sriwijaya Research in 2017, which has been funded this research complies with the letter of Agreement Assignment of Competitive Grants Research Universitas Sriwijaya in 2017.

\section{REFERENCES}

1. Acemoglu, D. 2002. Technical Change, Inequality and the Labor Market. Journal of Economic Literature 40: 7-72.

2. Adams, M.E. 1988. Agricultural Extension in Developing Countries. First Edition. Longman Singapore Publisher Pte Ltd. Singapore.

3. Adriani, Dessy. 2015. Rasionalitas Sosial Ekonomi Dalam Penyelesaian Pengangguran Terselubung Petani Padi Sawah Tadah Hujan . MASYARAKAT: Jurnal Sosiologi 20 (1): 43-58.

4. Agus, F. dan Irawan. 2007. Agricultural land conversion as a threat to food security and environmental quality. Jurnal Penelitian dan Pengembangan Pertanian 25(3):90-98.

5. Ali, Muhammad. 2014. Prospek Lahan Rawa Pasang Surut Untuk Tanaman Padi. Prosiding Seminar Nasional Inovasi Teknologi Pertanian Spesifik Lokasi. Banjarbaru: Balai Penelitian Pertanian Lahan Rawa.

6. Becker, Garry S. 1965. A Teory of the Allocation of Time. Economic Jurnal. 75(299).

7. Bennett, N. (2010). Sustainable livelihoods from theory to conservation practice: An extended annotated bibliography for prospective application of livelihoods approaches in protected area community research, 55. Retrieved from http://dspace.library.uvic.ca:8080/handle/1828/4461

8. Bartelsman, Eric J., Gautier P. A., dan J. de Wind. 2010. Employment Protection, Technology Choice, and Worker Allocation. The Institute for the Study of Labor (IZA). IZA DP No. 4895. April 2010.

9. Ilis, F. (1999). Rural Livelihood Diversity in Developing Countries: Evidence and Policy Implications. ODI Natural Resource Perspectives, 40(40), 1-10. https://doi.org/xx

10. Fabrero, R., and P.S. Schwatrz. 2000. The Essence of Becker. Hoover Institution Press. Stanford University. California.

11. Granou, R. 1976. Leisure, Home Production and Work. The Theory of The Alocation of Time Revised. Journal of Political Economy 86 (6): 1099-1124.

12. Grist. D.H. 1960. Rice. Formerly Agricultural Economist, Colonial Agricultural Service, Malaya. London: Longmans, Green and Co Ltd.

13. Gujarati, D. 1993. Ekonometrika Dasar. Cetakan ketiga. Jakarta: Erlangga.

14. Musyafak, Akhmad Dan T. M. Ibrahim. 2005. Strategi Percepatan Adopsi Dan Difusi Inovasi Pertanian Mendukung Prima Tani. Analisis Kebijakan Pertanian. Volume 3 No. 1, Maret 2005: 20-37.

15. Nakajima, C. (1986). Subjective Equilibrium Theory of The Farm Household. Elsevier Science Publisher. Amsterdam.ISBN:0-444-42646-9.

16. Norsida Man, \& Sami Ismaila Sadiya. (2009). Off-Farm Employment Participation Among Paddy Farmers in the Muda Agricultural Development Autority and Kemasin Semerak 
Ganary Areas of Malaysia. Asia-Pasific Development Journal, 16(2), 141-154. https://doi.org/10.18356/be439b1f-en.

17. Panggabean, E.W., Dan B.Y. Angguniko. 2014. Kebijakan Pengembangan Irigasi Rawa Pasang Surut Dengan Pendekatan Sistem Dinamik. Puslitbang Kebijakan Dan Penerapan Teknologi. Balitbang Kementerian Pekerjaan Umum Dan Perumahan Rakyat. Jakarta.

18. Pindyck, R. S. and D. L. Rubinfeld. 1991. Econometries Models, and Economies Forecast. 3rd. ed. McGraw-Hill Edition. Singapore.

19. Riyani, Rita. Radian, Setia Budi. 2013. Pengaruh Berbagai Pupuk Organik Terhadap Pertumbuhan Dan Hasil Padi Di Lahan Pasang Surut. Jurnal Sains Mahasiswa Pertanian 2 (2). Untan.

20. Simamora, Bilson. 2003. Membongkar Kotak Hitam Konsumen. PT. Gramedia. Jakarta. 